\title{
European Intellectual Property Institutions and Chinese Foreign Direct Investment
}

\section{Introduction}

At a global scale, the role of strengthening IP institutions in attracting or discouraging foreign direct investment (FDI) is ground-breaking. Recent empirical studies have provided evidence on the effect of IP institutions on inward FDI from multiple countries or on the effect of IP institutions on the outward FDI levels originating from one country. Despite the emerging evidence, there is still increasing concern by European policymakers on the access that Chinese companies gain on Europe's key technologies and sensitive infrastructure. It seems that the Chinese OFDI has not been greeted with enthusiasm but with a great deal of concern (Knoerich and Vitting, 2018). Taking stock of the scant research evidence on the impact of European IP institutions on Chinese OFDI we contribute to the literature by providing insightful results using a novel estimation methodology, namely the quantile panel regression.

According to Dunning (1993), the key motivations for outward FDI are market-seeking, efficiency-seeking (cost reduction), and resource-seeking, including both natural resourceseeking and strategic asset-seeking. These are directly linked to the interaction between three key sources of competitive advantage, namely ownership-specific, location-specific and internalization-specific effects, the so-called O-L-I paradigm (Dunning, 2006). These three components are embedded within institutions and are inextricably linked to the "cognition, motivations and behaviour of MNEs" (Dunning and Lundan, 2008: 580).

In this context, Chinese firms' decisions to invest in Europe should be motivated by those features currently dominating the global economic landscape. As Buckley et al. (2008) posit, key features such as tariff barriers, supply-chain bottlenecks, or limited growth opportunities and intensified competition in the home market, are contemplated by Chinese investors when 
targeting the EU market. For example, the wholesale and retail trade services and transport, storage and postal services are few of the most attractive sectors (MOFCOM, 2013) where potential growing demand in the EU region might indeed attract Chinese investment. Given that China is a relatively low-cost labour economy one might assume that efficiency is not a typical incentive for Chinese investors (Buckley et al., 2007; Chou et al., 2011). Nevertheless, there is evidence suggesting that in some instances Chinese investors might target other lowcost labour countries (Clegg and Voss, 2011). Over the recent years, Chinese firms focus on regions rich in natural endowments such as the EU mining industry (Buckley et al., 2007; Kolstad and Wiig, 2012; MOFCOM, 2013). Recently, emerging evidence suggests that technologies, brand names and distribution channels have been instrumental in shaping new patterns of strategic behaviour for many Chinese investors through mergers and acquisitions (Buckley et al., 2007; Luo and Tung, 2007; Rugman and Li, 2007; Cui and Jiang, 2010). Additional evidence suggests that, in the short run, profit maximization is far from being a primary objective associated with Chinese OFDI as Chinese investors have been establishing research and development centres in Europe as a means of upgrading knowledge-intensive product manufacturing in China (Bonaglia et al., 2007; Minin et al., 2012). This provides support to the view that unconventional patterns of internationalization have been exhibited by Chinese firms investing overseas (Mathews, 2002; Sanfilippo, 2015).

In so far as OFDI motivation and institutional effects relating to each O-L-I dimension is concerned, evidence suggests that Chinese firms gain ownership-specific advantages from home institutions (Sun et al., 2012; Wang et al., 2012), networking with government institutions (Yiu et al., 2007) or operating within business groups that are supported by governments (Pangarkar and Wu, 2012). Location choices in foreign markets are also affected by institutional elements such as cultural proximity or governance structure (e.g., Buckley et al., 2007; Shieh and Wu, 2012). In particular, Chinese firms potentially gain internalization- 
specific advantages through the selection of governance structures that are congenial to them such as wholly-owned subsidiaries, joint ventures and mergers and acquisitions (Cui and Jiang, 2009; e.g., Rui and Yip, 2008; Sun et al., 2012; Zhang, et al., 2011).

Currently, the empirical evidence on the relationship between the strength of IP institutions of European countries on Chinese OFDI is scarce. Indicatively, only the studies by Boisot (2004), Nolan (2001) and Rui and Yip (2008) discuss the effects of the home IP institution on Chinese OFDI whilst Wei et al. (2014), by exploring the effect of the home IP institution as a means of enhancing China's OFDI, find a positive effect. Additionally, Papageorgiadis et al. (2019) following a dynamic panel data analysis, established that the strength of IP institutions positively affects OFDI from China whilst weak evidence of a potential U-shaped relationship was produced. The related literature concedes that institutional factors can potentially motivate Chinese firms to invest abroad (e.g., Hoskisson et al. 2013; Liang et al. 2012; Peng et al. 2008; Rui and Yip 2008; Witt and Lewin 2007; Deng 2013). Whilst there is some evidence that explores the impact of historically weak protection of Chinese IP at home (Boisot 2004; Wei et al. 2014) (Globerman and Shapiro 2009; Klossek et al. 2012), the potential effects of the IP institutions of host countries on Chinese OFDI have so far not been empirically tested.

In addition, empirical studies based on country-level data (Buckley et al. 2007; Kolstad and Wiig 2012; Cheung and Qian 2009) have predominately focused on Chinese OFDI directed to the global market without exploring regional-specific effects. Among the few exceptions are the studies of Kang and Jiang (2012) and Cheung et al. (2012) which focus on Asia and Africa respectively. According to Buckley et al. (2008), Chinese outward investors to the EU markets face institutional challenges that relate to institutional and economic conditions that EU countries experience as well as to the inherent difficulties when engaging in separate negotiations with investment agencies at both national and regional level. 
This paper contributes to the literature pertaining to the impact of the strength of European IP institutions on Chinese OFDI. We model the drivers of China's OFDI in relation to the European IP institutions, using the quantile panel regression that assumes a non-parametric form for the conditional distribution of OFDI, hence, providing information that would not be obtained directly from standard regression methods. In other words, such an empirical treatment provides us with a more insightful way of measuring the regression relationship at several points of the conditional distribution of the dependent variable simultaneously.

The rest of the paper is organized as follows: section 2 elaborates on the theoretical framework pertaining the effect of the strength of European IP institutions in attracting or discouraging Chinese OFDI whilst section 3 presents the data and the methodology adopted. Section 4 discusses the results and section 5 provides concluding remarks and policy implications.

\section{Theoretical considerations}

In an endeavour to provide a comprehensive and insightful definition of institutions, North (1990) likens institutions to human and social constructs that condition both human and organizational behaviour through a set of rules, procedures, powers of enforcement and norms of behaviour. In the same spirit, Scott (1995) draws parallels between institutions - such as governments, courts and firms - and a set of structures - such as laws and regulations - that promote a stable and a transparent environment within which agents' activities take place (Orr and Scott, 2008). By making a distinction between normative and cognitive structures, Scott (1995) purports to link normative structures to the tacit elements established and integrated within an institution, and the cognitive structure to the broader values that society is exposed to such as cultural aspects that consist of perceptions and explanations of social reality perceived by the agents operating within the institution. In view of the above, it becomes 
apparent that the effectiveness of the enforcement of regulations is directly related to the perception of both normative and cognitive structures.

The extent to which the strength of the regulatory structure of the IP institutions of different countries is effectively enforced by the normative and cognitive structures of their institutions varies. Institutional distance between two countries is determined by the degree of similarity or difference between their institutions (Kostova, 1996; Kostova and Zaheer, 1999). Institutional differences affect international business activity, especially when the distance is high, such as for investments between industrialised and less industrialised economies (where distance is commonly expected to be high). As Xu and Shenkar (2002: 614) highlight, "from an institutional perspective firms will refrain from investing in markets that are institutionally distant, because business activities in those markets require conformity to institutional rules and norms that conflict with those of the home country". This is because firms seeking to appropriate value from their assets in a foreign market need to ensure that they comply (both internally and externally) with the rules and norms instigated by host country institutions (DiMaggio and Powell, 1983). Similarly, for multinational enterprises (MNEs) originating from countries with strong institutions, the well-functioning of host country institutions is generally expected to have a positive influence on their location selection, mode of entry and technology transfer strategies (Dunning, 2006; Henisz and Swaminathan, 2008; Meyer and Hung Vo, 2005).

The level of the overall strength of IP institutions is significantly and distinctively different between countries worldwide (Kanwar and Evenson, 2009; Park, 2008; USTR, 2014). After the signing of the Trade-Related Aspects of Intellectual Property Rights (TRIPs) agreement in 1994, developed and developing countries followed a linear strengthening policy trajectory by reforming their IP regulatory frameworks (Taubman, Wager, and Watal, 2012). 
The aim was to create IP institutions that offer stronger levels of IP regulatory protection and thereby achieve relative harmonization with the IP institutions of other countries (Grossman and Lai, 2004). Although the TRIPs agreement set up minimum regulatory levels that the member countries are obliged to comply, it did not specify maximum standards of regulatory protection or reform obligations for the actual enforcement aspect of the IP institution (Taubman et al., 2012).

\section{IP institutions and FDI}

The impact of strengthening IP institutions on FDI has recently started receiving additional currency, stimulating several empirical studies that have reported evidence on the effect of IP institutions on either inward FDI or outward FDI originating from one country. This evidence suggests that there is a positive relationship between strong IP institutions and FDI flows particularly in developing countries (e.g., Alexiou et al., 2016; Adams, 2010; Nicholson, 2007; Seyoum, 2006; Smarzynska Javorcik, 2004). On the effects of the regulatory structure of host IP institutions on inward FDI, Smarzynska Javorcik (2004) established a highly significant positive relationship. The same positive and significant relationship was also confirmed when a variable that captures the strengthening of the enforcement-related aspects of host IP institutions of transition economies was factored into the specification of the estimation model. Khoury and Peng (2011), however, in a study of 18 Latin American economies found that IP regulatory reforms adversely affect inward FDI flows whilst a positive effect on inward FDI is observed for the early IP reforming countries, in particular, those countries with an already developed innovation base.

A similar positive effect on inward FDI is also identified in the results of studies that focus on the strengthening of the regulatory structure of the IP institution in single country studies (Awokuse and Yin, 2010; Du et al., 2008; Seyoum, 2006). For example, Awokuse and Yin 
(2010) studied the regulatory strengthening of the Chinese IP institution and found that stronger IP regulations and the rise in foreign patent applications in the early 1990s had a highly significant and positive effect in attracting FDI from 38 countries to China. This effect was significant for inward FDI from all countries independent from their level of income or development. This evidence was also confirmed by Du et al. (2008) who used a proxy for the strengthening of the Chinese IP institution based on the per capita absolute numbers of approved patents in different Chinese regions over the years 1993-2001 and found a positive effect in attracting FDI from the US. Finally, Kondo (1995) finds no significant relationship between stronger IP levels and inward FDI.

As far as the impact of stronger IP institutions on outward FDI is concerned, the extant empirical literature suggests that countries with strong IP institutions appear to attract higher OFDI levels (Bascavusoglu and Zuniga, 2002; Branstetter et al., 2007; Lee and Mansfield, 1996; Ushijima, 2013). In particular, the strengthening of the regulatory framework of IP institutions is associated with a positive impact of OFDI (Branstetter et al., 2007; Lee and Mansfield, 1996). In this context, Branstetter et al. (2007) find that patent regulatory reforms in patent-intensive industries, over the period 1989-1999, have a significant positive impact on US OFDI. Similar results were also obtained by Lee and Mansfield (1996)) whilst for Canals and Şener (2014) the impact is only evident in the high-tech sector.

Further evidence on the positive effect of the regulative structures of IP institutions on OFDI was also produced in additional studies by (Bascavusoglu and Zuniga, 2002; Etienne and Bruno, 2005; Ushijima, 2013), whilst the evidence generated by Etienne and Bruno (2005) suggests that strengthening IP levels have no significant effect on the OFDI levels. More specifically, the strengthening of IP legislation is found to have a negative effect on French 
OFDI in the context of those countries that boast a large market as well as those that are characterized by relatively low levels of RandD intensity (Etienne and Bruno, 2005).

In addition, anecdotal evidence suggests that motivations of Chinese firms' investments in the EU market share some similar features to those demonstrated in the global market. Chinese investors may defensively target the EU market due to tariff barriers, supply-chain bottlenecks, or limited growth opportunities and intensified competition in the home market (Buckley et al., 2008). They may also offensively target EU countries for their scale of potential demand. Seeking efficiency is not a typical incentive given that China still provides cheap factors of production (Buckley et al., 2007; Chou, Chen, and Mai, 2011). Nevertheless, some Chinese investors actively target countries such as Romania specifically because of their relatively low labour costs (Clegg and Voss, 2011). Chinese firms specifically target regions rich in natural endowments (Buckley et al., 2007; Kolstad and Wiig, 2012). For example, the EU mining industry is one of the top five most invested industries by Chinese OFDI (MOFCOM, 2013) ${ }^{1}$. In addition, recent research indicates that Chinese firms are determined to access and acquire strategic assets such as technologies, brand names and distribution channels (Buckley et al., 2007; Luo and Tung, 2007; Rugman and Li, 2007) via mergers and acquisitions (Cui and Jiang, 2010). Profit maximization may not be the primary objective associated with Chinese OFDI in the short-run (Kang and Jiang, 2012; Ramasamy, Yeung, and Laforet, 2012). Instead, Chinese investors have actively set up R\&D centres in Europe in order to upgrade knowledge-intensive product manufacturing in China (Bonaglia, Goldstein, and Mathews, 2007; Minin, Zhang, and Gammeltoft, 2012). In summary, Chinese firms investing overseas display "unconventional" patterns of internationalization (Mathews, 2002; Sanfilippo, 2015).

\footnotetext{
${ }^{1}$ According to Han (2019) the leading industries for China's outward FDI stock in billions of U.S. dollars in Europe by the end of 2017 were as follows: Manufacturing 34.13, Mining 22.5, Financial services 17.72, Leasing and business services 10.63 and Wholesale and retail trade 5.17.
} 
A number of empirical studies on the motivations of Chinese outward investors highlight the institutional effects relating to each O-L-I dimension. Chinese firms gain ownershipspecific advantages from home institutions if they are state-owned (Sun, Peng, Ren, and Yan, 2012; Wang, Hong, Kafouros, and Boateng, 2012), network with government institutions (Yiu, Lau, and Bruton, 2007) or stay with business groups for government supports (Pangarkar and $\mathrm{Wu}, 2012)$. Institutions also affect their location choices in foreign markets. Often Chinese outward investors tend to select locations with high cultural proximity (e.g., Buckley et al., 2007; Shieh and $\mathrm{Wu}, 2012)$. Furthermore, institutions affect how Chinese firms gain internalization-specific advantages via the selection of a governance structure such as the wholly-owned subsidiaries, joint ventures (Cui and Jiang, 2009) and mergers and acquisitions (e.g., Rui and Yip, 2008; Sun et al., 2012; Zhang, Zhou, and Ebbers, 2011).

However, there are currently very few studies investigating the effect of the strength of IP institutions of host countries on Chinese OFDI. A limited number of studies discussed the effects of the home IP institution as a supporting pillar of Chinese OFDI (e.g., Boisot, 2004; Nolan, 2001; Rui and Yip, 2008). Focusing on the effect of the home IP institution at the subnational level, Wei et al. (2014) examined the impact on enhancing China's OFDI and found a positive effect.

As the literature on the effect of strengthening IP institutions on OFDI appears to be maturing, there are currently only a few studies that investigate the role of the IP institution on OFDI originating from China. As discussed earlier, OFDI from China has different characteristics compared to Western countries. Given the low level of strength of the enforcement-related aspects of the IP institution in China (Boisot, 2004; Papageorgiadis et al., 2014), it is important to investigate whether or not Chinese OFDI is affected by the IP institutional environment of foreign countries in a similar way as OFDI from developed countries. In so doing, we explore 
the extent to which the strength of IP institutions impacts Chinese OFDI into the European economies which enforce regulations to varying degrees of strength.

\section{Data and Methodology}

We formulate and estimate a model for a sample of 21 European economies over the period 2003-2015. The main objective of this study is to gauge the impact of the strength of the IP institutions on Chinese OFDI given the diverse economic and IP strength characteristics of the European countries in the sample. Also, the study aims at establishing the significance of other potential determinants of OFDI in line with the related literature. Table 1 in the appendix presents the European countries in our sample that were selected based on available data. It is noted that all 21 countries in our dataset are WTO members and boast relatively strong IP regulations.

\subsection{Methodological Framework}

The usual linear regression model considers the relationship between a group of explanatory variables, $X$, and a response variable, $y$, based on the conditional mean function $E(y \mid X)$. Accordingly, this model provides a rather narrow measure of the relationship, based on just one moment of the (conditional) distribution of $y$. However, it should be valuable to assess the relationship between $y$ and $X$ at different points in this conditional distribution, as answers to important questions are in modeling the tails of the conditional distribution, in other words, the devil is in the detail. In view of the latter, we have opted for panel quantile regression $(\mathrm{QR})$ which provides a way of measuring the regression relationship at several points of the conditional distribution of $y$ simultaneously. Based on the absolute values of the regression 
residuals, QR is more robust to sample outliers and the non-normality of the error terms than is the OLS regression. The resulting estimator exhibits desirable asymptotic (large- $n$ ) properties, and unlike OLS the regression results are invariant to monotonic transformations of y. Quantile regression traces its origins to the seminal paper by Koenker and Bassett (1978), but its roots lie deeper than that. In particular, the essential ideas can be traced back to very early contributions by Boscovich, Laplace, Gauss, and Edgeworth, as early as the mid-18 th Century.

Overall, QR is more robust to non-normal errors and outliers; it permits a richer characterization of the data by allowing us to consider the impact of a covariate on the entire distribution of $y$, not merely its conditional mean. The regression model for quantile level $\tau$ of the response is given by:

$$
Q_{\tau}\left(y_{i}\right)=\beta_{0}(\tau)+\beta_{1}(\tau) x_{i 1}+\ldots+\beta_{p}(\tau) x_{i p}, i=1, \ldots, n
$$

and the $\beta_{j}$ 's are estimated by solving the least squares minimization problem:

$$
\min _{\beta_{0(\tau)}, \ldots, \beta_{p(\tau)}} \sum_{i=1}^{p} \rho_{\tau}\left(y_{i}-\beta_{0}(\tau)-\sum_{j=1}^{p} x_{i j} \beta_{j}(\tau)\right)
$$

where $\rho_{\tau}(r)=\tau \max (r, 0)+(1-\tau) \mid \max (-r, 0)$. Then, for each quantile level $\tau$, the solution to the minimization problem yields a distinct set of regression coefficients. In this context, the empirical specification of the OFDI regressions is a variant of the standard specifications encountered in the literature (see Buckley et al. 2007; Kolstad and Wiig 2012; Ramasamy and Yeung 2010). The estimated equation is expressed as follows:

$$
O F D I i_{i t}=a_{0}+a_{1}\left\{\begin{array}{l}
I P E_{i t} \\
\operatorname{IPRI}_{i t}
\end{array}+a_{2}\left\{\begin{array}{c}
\text { IPSQ }_{i t} \\
\text { IPRISQ }_{i t}
\end{array}+\varphi_{1} X_{i t}+\varepsilon_{i t}\right.\right.
$$


where $O F D I_{i t}$ is the logarithm of Chinese outward FDI flows to selected European economies (see Table 1) and $X_{i t}$ is a vector of variables that are thought to significantly condition OFDI; i.e. GDPPC is the logarithm of GDP per capita of the respective countries; $P O P$ denotes the logarithm of population; TRADE is a measure of trade openness; ULC denotes unit labour costs - an alternative measure that was also used was $L B P R O D$ denoting labour productivity - ; IPE is the level of IP strength proxied by Papageorgiadis et al. (2014) whereas IPRI is an alternative measure capturing International Property Rights index and $\varepsilon_{t}$ is the disturbance term. The squared terms - IPESQ and IPRISQ - of both IP indices have also been incorporated in our modeling effort to account for non-linearities. The definitions of variables used as well as the descriptive statistics and the cross-correlation matrix are provided in Tables 2 to 4 respectively, in the appendix.

\subsection{The Variables}

The dependent variable is the stock of Chinese outward FDI (OFDI). The key independent variable is the strength of European IP institutions proxied by a recently developed version of the Index for Patent Enforcement (IPE) developed by Papageorgiadis et al. (2014) which measures the strength of IP institutions. IPE follows the theoretical underpinnings of transactions cost theory and estimates the level of transactions cost that IP-owning firms face when engaging with a national patent system. A country's score is the aggregate of three transaction-cost constructs, namely: a) servicing costs, b) property right protection costs and c) monitoring $\operatorname{costs}^{2}$. High scores in the index indicate an efficient and effective IP institution where the

\footnotetext{
2 The servicing costs construct accounts for the efficiency of the administration process by public and private agencies. The property rights protection costs construct measures the costs that originate from the effectiveness of the judiciary system. The monitoring cost construct measures the costs that firms experience when they engage with the enforcement agencies of a country (Papageorgiades et al., 2019).
} 
regulative, normative and cognitive structures are aligned, and IP-owning firms experience few transaction costs when interacting with the institution. The monitoring cost construct measures the costs that firms experience when they engage with the enforcement agencies of a country. The property rights protection costs construct measures the costs that originate from the effectiveness of the judiciary system. The servicing costs construct accounts for the efficiency of the administration process by public and private agencies. In the European context where all 21 countries in our dataset are WTO members and boast relatively strong IP regulations, high scores in the index indicate an efficient and effective IP institution where the regulative, normative and cognitive structures are aligned and IP-owning firms experience few transaction costs when interacting with the institution. Lower scores suggest that while the regulative structure of the institution is strong, the normative and cognitive structures are not aligned and therefore IP-owning firms are faced with an inefficient and ineffective IP institutional framework and therefore find it difficult to enforce their rights.

For robustness and comparative reasons, we also utilize an alternative measure - the International Property Rights Index (IPRI) - which is based on three main elements: a) legal and political environment; b) physical property rights; c) intellectual property rights. ${ }^{3}$

Regarding the selection of the other control variables, we incorporate in our model a host of variables that have been inter alia identified as main determinants of outward FDI by previous research studies. These are GDP per capita, population, trade and unit labour costs (for a more comprehensive review see Chakrabarti (2001) and Blonigen (2005)). GDP per capita captures the market potential of an economy whilst the population is a proxy for the market size of the respective countries ${ }^{4}$. Existing evidence suggests that market potential and market size are

\footnotetext{
${ }^{3}$ For more details see https://www.internationalpropertyrightsindex.org/about ${ }^{4}$ The impact of the market size on OFDI is proxied by the size of the population rather than GDP because
according to Chakrabarti (2001) the absolute GDP is a poor indicator.
} 
positively related to FDI inflows since economic growth acts as a catalyst for the efficient utilization of resources and the exploitation of economies of scale via FDI (Chakrabarti 2001; UNCTAD 1998). Evidence suggests that large and growing markets are particularly targeted by Chinese multinational enterprises (Buckley et al. 2007; Kolstad and Wiig 2012; Kang and Jiang 2012). We have also included the trade variable in our model as the more extrovert and hence the more "open" a country is to foreign capital, the more likely is to attract FDI (Chakrabarti 2001). Trade openness is therefore expected to be positively related to Chinese OFDI.

Unit labour costs have also been used as a potential determinant as the existing empirical evidence relating to their impact on OFDI is inconclusive. For instance, in a study that consists of selected Central and Eastern European Countries over the period 1995-2003, Bellak et al. (2008) find that higher unit labour costs affect FDI negatively, whereas higher labour productivity impacts positively on FDI. In general, we should expect that increasing unit labour cost will reduce competitiveness - productivity, thus, shaping a less attractive environment for FDI. Dreger et al. (2017) however state that higher labour costs do not affect the involvement of Chinese investors in existing firms; as China possesses competitive advantages with regards to low wages and qualified labour, lower costs are not the main driver for FDI in developed countries. In addition, Nicolas (2014) argues that China's direct investment in the European Union tends to be concentrated in non labour-intensive sectors.

\section{Results and Discussion}

We estimate five different models - each corresponding to different points at the conditional distribution - to test the effect of the strength of European IP institutions on Chinese OFDI in different clusters of the countries in the sample of countries. Table 1 presents the results from the panel quantile regressions using IPE of Papageorgiades et al. (2014). 


\section{INSERT TABLE 1 ABOUT HERE}

The results suggest a negative and significant relationship between Chinese OFDI and strong levels of IP institutions in the median and upper quantiles of our dataset. In these quantiles, that consist of the median to high-OFDI recipient countries, the strength of IP rights negatively affects Chinese FDI, other factors remaining constant. While this effect was not studied in the context of Chinese OFDI before, the negative effect of strong IP institutions in attracting OFDI is not consistent with the majority of existing studies on OFDI from developed economies (Branstetter et al. 2007; Lee and Mansfield 1996; Ushijima 2013). These studies suggest that a potentially positive effect could be attributed to the eagerness of Chinese firms to access strategic assets (Rui and Yip 2008) and upgrade their competitiveness at a global level (Deng 2007; Hong and Sun 2006; Deng 2013). A key aspect in the upgrading process is to escape from the poor IP institutional framework existing in China (Boisot and Meyer 2008) and develop an understanding and compliance with strong IP institutions that are boasted by most developed economies. This is because even if many of the Chinese firms are market leaders in China (Clegg and Voss 2011), the lack of a developed IP framework (Boisot 2004), local protectionism (Nolan 2001), and imbalanced institutional development in their home market (Boisot and Meyer 2008) can impose high institutional costs on Chinese firms when competing in strong IP institutions.

Notwithstanding, the negative sign in IPE may also imply that the lower the strength of European IP institutions the higher the Chinese OFDI received. This result is consistent with the conventional expectation that firms prefer to invest in institutionally similar countries $(\mathrm{Xu}$ and Shenkar 2002). In this context, European countries boasting a moderate level of IP institutional strength may convey mixed signals to Chinese investments. Chinese firms may prefer the predictability of a weak IP institution in terms of lack of IP enforcement which, at 
the very least, poses a limited risk to a Chinese firm's business model (established at home) from the potential enforcement actions by competitors. In contrast, European IP institutions boasting a moderate level of strength may be unpredictable for Chinese firms which would prefer to avoid entering potentially lengthy and costly IP enforcement efforts when defending their IP assets or when being sued for the infringement of the IP of third parties.

It should be stressed that the generated evidence in this study provides the first empirical investigation in the literature on the importance of the strength of IP institutions for OFDI from an emerging market by looking at several points of the conditional distribution of OFDI. The findings are not in line with the evidence produced by studies on OFDI from both developed and developing countries which suggest that that strong IP institutions act as a gravitational point for higher levels of OFDI (Nicholson, 2007; Seyoum, 2006; Smarzynska Javorcik, 2004, Papageorgiades et al., 2019). Furthermore, it appears that strong IP institutions might deter Chinese IP-owning firms to engage in innovation activities in the host country. The latter is to an extent counter to what is expected as countries with strong IP institutions, supportive to the IP regulatory structure.

As far as the non-linear effects are concerned, the positive and significant square term implies convexity, i.e. there is a lower IP strength limit before OFDI starts increasing again. More specifically, the U-shaped relationship between the strength of IP institutions and Chinese OFDI is in line with Papageorgiades et al. (2019) . It can, therefore, be argued that Chinese firms may be attracted to weaker IP institutions because they share institutional similarities with the host countries. In this context, Buckley et al. (2007) and Yiu et al. (2007) have suggested that countries transitioning from centrally planned to market economies develop

\footnotetext{
${ }^{5}$ The context of their analysis is somewhat different as the nonlinear effect was significant in the case where a sample of former eastern-bloc countries was considered.
} 
business and institutional ties with similar economies so as to control the institutional environment. In this sense, weaker IP institutional strength provides an opportunity for a Chinese firm to develop ties with institutional agents so as to reduce the potential IP enforcement impact by competitors.

The majority of the control variables included in the estimation have a positive and significant effect on Chinese OFDI. More specifically, population and GDP per capita are found to have a significant positive effect on Chinese OFDI which is in line with the theoretical expectations (see Chakrabarti, 2001). In addition, market openness reflected by trade bears the expected positive sign (Ahmad et al, 2018) and is found to have a significant effect on Chinese OFDI. A stark observation that derives from our results is the positive and highly significant effect of ULC on Chinese outward FDI. Similarly, when we estimate the model with labor productivity ${ }^{6}$ instead of ULC, we find a negative and significant relationship with OFDI across all, except the 0.75 , quantiles. Overall, it appears that both variables - high labor productivity and unit labor costs - covey mixed signals to prospective Chinese investors.

To test the robustness of the results obtained using IPE we have also used an alternative measure of patent enforcement, namely the International Property Rights Index (IPRI) which scores the underlining institutions of a strong property rights regime: the legal and political environment, physical property rights, and intellectual property rights. Table 2 presents the quantile regression results obtained through the use of IPRI.

\section{INSERT TABLE 2 ABOUT HERE}

Broadly in line with the results obtained using the IPE index, it appears that the IPRI index becomes significant only in the upper quantiles of 0.75 and 0.9 supporting the view that

\footnotetext{
${ }^{6}$ We have opted to use labour productivity as an alternative measure of unit labour costs for robustness check, given the inconclusiveness in the empirical studies. These results, not presented here are available upon request.
} 
institutional strength in terms of patent enforcing may discourage Chinese investment in Europe. Such a finding may imply that European countries pose a sophisticated legal apparatus while the legislation of the EU adds still another layer of complexity (Corre, 2018). On one hand, Chinese investors who wish to invest in an open Europe would need to understand and accept its system that comes with increased costs whilst on the other hand, European policymakers should follow a common and consistent approach and coordinate the investment monitoring and filtering processes for the benefit of their citizens.

In contrast to the IPE results in Table 1, the effect of GDP per capita in the case of IPRI remains insignificant across all quantiles. However, all other variables, i.e TRADE, POP and ULC maintain a solid positive effect across all quantiles which in the case of TRADE and ULC diminishes in the upper quantile (0.9) suggesting that other factors may be in play when it comes to sizeable investments in European countries.

Figure 1 in the appendix displays the process graphs of both IPE - IPESQ, and IPRI - IPRISQ for different quantiles, along with a 95\% confidence interval. Furthermore, in Table 5 in the appendix, we provide the tests for the equality of the slope coefficients across quantiles and the symmetric quantiles test. In both cases (IPE and IPRI), the $X^{2}$-statistic values of 57.56 and 43.12 are statistically significant at conventional test levels as shown by the respective p-values in Table 5, suggesting that the slope coefficients are constant across quantiles. Also, the symmetric quantiles test which performs the Newey and Powell (1987) test of conditional symmetry produces $X^{2}$-statistic values of 19.50 and 1.34 , respectively, suggesting there is little evidence of departures from symmetry.

\section{Concluding remarks and policy implications}


The strength of international IP institutions and their effect on OFDI has received significant scholarly attention over the last two decades. Most studies focus on identifying the effect of IP institutions on OFDI from advanced economies, such as the US, Germany, and Japan. The existing empirical literature confirms the theoretical expectations in that high institutional differences between the home and the host countries negatively affect OFDI. However, this is the first empirical study that explores the effect of the strength of IP institutions on the OFDI from an emerging economy point of view at several points of the conditional distribution of OFDI.

Using two measures of IP institutions' strength we find a negative and most likely non-linear effect of European IP institutions on Chinese OFDI which becomes stronger in the median and upper-quantiles of recipient European countries.

Given that Chinese firms operate in a weak IP institutional environment in their home country, the findings are in line with conventional expectations that high institutional differences between countries negatively affect OFDI. This result also implies that Chinese investors appear to avoid locating in countries offering moderate levels of IP strength, possibly due to the unpredictability of the institutional costs that Chinese firms may face when operating in such markets. Overall, the results support the view that IP strengthening may not be supportive for Chinese investment in Europe while GDP per capita, population, trade openness and unit labour costs exert a positive effect on Chinese OFDI.

The novel evidence of this study has potentially important policy implications for both businesses and policymakers respectively as it suggests that the strengthening of national IP institutions might discourage OFDI from China. So far, the importance of the IP institution as a means of attracting Chinese OFDI has received little currency due to lack of relevant studies. In view of the new evidence in the respective literature, it is imperative that EU policy-makers 
redirect their effort to comprehending the inherent challenges that Chinese firms face when interacting with European IP institutions. In this context, different levels of IP strength appear to be significantly conditioning Chinese OFDI. The evidence suggests that Chinese companies are rather reluctant to advance capital outflows in countries with strong or moderate IP institutions. Overall, given that this is the first study exploring the effects of two different measure of IP institution on OFDI from an emerging economy, future studies could investigate if the effects are similar for the OFDI stemming from other emerging economies as well as identify the effects of the worldwide strengthening IP institutions on Chinese investments. 


\section{References}

Adams, S. (2010). Intellectual property rights, investment climate and FDI in developing countries. International Business Research, 3(3), 201-209.

Ahmad, F., Draz, M. and Yang, S. (2018), What drives OFDI? Comparative evidence from ASEAN and selected Asian economies, Journal of Chinese Economic and Foreign Trade Studies, Vol. 11 No. 1, pp. 15-31. https://doi.org/10.1108/JCEFTS-03-2017-0010

Alexiou, C., Nellis, J. and Papageorgiadis, N. (2016), The effect of patent enforcement strength and FDI on economic growth, Multinational Business Review, 24(4), 334353. https://doi.org/10.1108/MBR-07-2016-0024

Awokuse, T. O., \& Yin, H. (2010). Intellectual property rights protection and the surge in FDI in China. Journal of Comparative Economics, 38(2), 217-224.

Bascavusoglu, E., \& Zuniga, M. P. (2002). Foreign patent rights, technology and disembodied knowledge transfer cross borders: an empirical application [Unpublished manuscript]. France: University of Paris I.

Bellak, C., Leibrecht, M. \& Riedl, A. (2008) Labour costs and FDI flows into Central and Eastern European Countries: A survey of the literature and empirical evidence. Structural Change and Economic Dynamics, 19(1), p. 17-37.

Blonigen, B. A. (2005). A review of the empirical literature on FDI determinants. Atlantic Economic Journal, 33(4), 383-403.

Boisot, M. (2004). Notes on the internationalization of Chinese firms. Barcelona, Spain: Open University of Catalonia.

Boisot, M., \& Meyer, M. W. (2008). Which way through the open door? reflections on the internationalization of Chinese firms. Management and Organization Review, 4(3), 349-365.

Bonaglia, F., Goldstein, A., \& Mathews, J. A. (2007). Accelerated internationalization by emerging markets' multinationals: the case of the white goods sector. Journal of World Business, 42(4), 369-383.

Branstetter, L., Fisman, R., Foley, C. F., \& Saggi, K. (2007). Intellectual property rights, imitation, and foreign direct investment: theory and evidence (No. w13033). National Bureau of Economic Research.

Buckley, P. J., Clegg, L. J., Cross, A. R., Liu, X., Voss, H., \& Zheng, P. (2007). The determinants of Chinese outward foreign direct investment. Journal of International Business Studies, 38(4), 499-518. 
Buckley, P. J., Cross, A. R., Tan, H., Xin, L., \& Voss, H. (2008). Historic and emergent trends in Chinese outward direct investment. Management International Review, 48(6), 715-748.

Canals, C., \& Şener, F. (2014). Offshoring and intellectual property rights reform. Journal of Development Economics, 108, 17-31.

Chakrabarti, A. (2001). The determinants of foreign direct investments: sensitivity analyses of cross-country regressions. Kyklos, 54(1), 89-114.

Cheung, Y.-W., de Haan, J., Qian, X., \& Yu, S. (2012). China's outward direct investment in Africa. Review of International Economics, 20(2), 201-220.

Cheung, Y.-W., and Qian, X. (2009). Empirics of China's outward direct investment. Pacific Economic Review, 14(3), 312-341.

Chou, K.-h., Chen, C.-h., \& Mai, C.-c. (2011). The impact of third-country effects and economic integration on China's outward FDI. Economic Modelling, 28(5), 2154-2163.

Clegg, J., \& Voss, H. (2011). Inside the China-EU FDI Bond. China and World Economy, 19(4), 92-108.

Corre, P. (2018) Chinese Investments in European Countries: Experiences and Lessons for the "Belt and Road" Initiative. Chapter in "Rethinking the Silk Road China's Belt and Road Initiative and Emerging Eurasian Relations" Mayer, M. (Ed.) Palgrave Macmillan, Singapore.

Cui, L., \& Jiang, F. (2009). FDI entry mode choice of Chinese firms: a strategic behavior perspective. Journal of World Business, 44(4), 434-444.

Cui, L., \& Jiang, F. (2010). Behind ownership decision of Chinese outward FDI: resources and institutions. Asia Pacific Journal of Management, 27(4), 751-774.

Deng, P. (2013). Chinese outward direct investment research: theoretical integration and recommendations. Management and Organization Review, 9(3), 513-539.

DiMaggio, P. J., \& Powell, W. W. (1983). The iron cage revisited: institutional isomorphism and collective rationality in organizational fields. American Sociological Review, 48(1), 147160 .

Dreger, C., Schüler-Zhou, Y. \& Schüller, M. (2017). Determinants of Chinese direct investments in the European Union. Applied Economics, 49:42: 4231-4240.

Du, J., Lu, Y., \& Tao, Z. (2008). Economic institutions and FDI location choice: evidence from US multinationals in China. Journal of Comparative Economics, 36(3), 412-429.

Dunning, J. H. (1993). Multinational enterprises and the global economy. Berkshire: Wokingham. 
Dunning, J. H. (2006). Towards a new paradigm of development: implications for the determinants of international business activity. Transnational Corporations, 15(1), 173-229.

Dunning, J. H., \& Lundan, S. M. (2008). Institutions and the OLI paradigm of the multinational enterprise. Asia Pacific Journal of Management, 25(4), 573-593.

Etienne, P., \& Bruno, D. (2005). Patent protection, strategic FDI and location choices: empirical evidence from French subsidiaries' location choices in emerging economies. International Journal of the Economics of Business, 12(3), 329-346.

Globerman, S., \& Shapiro, D. (2009). Economic and strategic considerations surrounding Chinese FDI in the United States. Asia Pacific Journal of Management, 26(1), 163-183.

Grossman, G. M., \& Lai, E. L. C. (2004). International protection of intellectual property. The American Economic Review, 94(5), 1635-1653.

Han, S. (2019) China's outward FDI stock in Europe 2017, by sector, Statista, https://www.statista.com/statistics/730070/china-outward-fdi-stock-europe-by-sector/.

Henisz, W., \& Swaminathan, A. (2008). Institutions and international business. Journal of International Business Studies, 39(4), 537-539.

Hong, E., \& Sun, L. (2006). Dynamics of internationalization and outward investment: Chinese corporations' strategies. The China Quarterly, 187(187), 610-634.

Hoskisson, R. E., Wright, M., Filatotchev, I., \& Peng, M. W. (2013). Emerging multinationals from mid-range economies: the influence of institutions and factor markets. Journal of Management Studies, 50(7), 1295-1321.

Kang, Y., \& Jiang, F. (2012). FDI location choice of Chinese multinationals in East and Southeast Asia: traditional economic factors and institutional perspective. Journal of World Business, 47(1), 45-53.

Kanwar, S., \& Evenson, R. (2009). On the strength of intellectual property protection that nations provide. Journal of Development Economics, 90(1), 50-56.

Khoury, T. A., and Peng, M. W. (2011). Does institutional reform of intellectual property rights lead to more inbound FDI?: evidence from Latin America and the Caribbean. Journal of World Business, 46(3), 337-345.

Klossek, A., Linke, B. M., \& Nippa, M. (2012). Chinese enterprises in Germany: establishment modes and strategies to mitigate the liability of foreignness. Journal of World Business, 47(1), $35-44$.

Knoerich, J. \& Vitting, S. (2018). Controversies and Contradictions about Chinese Investments in Europe. EuropeNow Journal 18, Council for European Studies (CES), Columbia University. 
Kolstad, I., \& Wiig, A. (2012). What determines Chinese outward FDI? Journal of World Business, 47(1), 26-34.

Kondo, E. K. (1995). The effect of patent protection on foreign direct investment. Journal of World Trade, 29(6), 97-122.

Koenker, R. \& G. W. Bassett, 1978. Regression quantiles. Econometrica, 46, 33-50.

Kostova, T. (1996). Success of the transnational transfer of organizational practices within multinational companies (Dissertation Thesis). University of Minnesota.

Kostova, T., \& Zaheer, S. (1999). Organizational legitimacy under conditions of complexity: the case of the multinational enterprise. The Academy of Management Review, 24(1), 64-81.

Lee, J.-y., \& Mansfield, E. (1996). Intellectual property protection and US foreign direct investment. The Review of Economics And Statistics, 78(2), 181-186.

Liang, X., Lu, X., \& Wang, L. (2012). Outward internationalization of private enterprises in China: the effect of competitive advantages and disadvantages compared to home market rivals. Journal of World Business, 47(1), 134-144.

Luo, Y., and Tung, R. L. (2007). International expansion of emerging market enterprises: a springboard perspective. Journal of International Business Studies, 38(4), 481-498.

Mathews, J. A. (2002). Dragon multinational: A new model for global growth. Oxford: Oxford University Press.

Meyer, K. E., \& Hung Vo, N. (2005). Foreign investment strategies and sub-national institutions in emerging markets: evidence from Vietnam. Journal of Management Studies, 42(1), 63-93.

Minin, A., Zhang, J., and Gammeltoft, P. (2012). Chinese foreign direct investment in RandD in Europe: a new model of RandD internationalization? European Management Journal, 30(3), 189-203.

MOFCOM (2013). Statistical Bulletin of China's Outward Foreign Direct Investment. Beijing, China: Ministry of Commerce of the People's Republic of China together with National Bureau of Statistics of China and State Administration of Foreign Exchange via China Statistics Press.

Newey, W.K. \& J.L. Powell, 1987, Asymmetric least squares estimation and testing, Econometrica 55, 819 - 847.

Nicholson, M. W. (2007). The impact of industry characteristics and IPR policy on foreign direct investment. Review of World Economics, 143(1), 27-54. 
Nicolas, F. (2014) China's direct investment in the European Union: challenges and policy responses. China Economic Journal, 7:1, 103-125.

Nolan, P. (2001). China and the global economy. Basingstoke, UK: Palgrave.

North, D. C. (1990). Institutions, institutional change and economic performance (Political economy of institutions and decisions). Cambridge, UK: Cambridge University Press.

Orr, R. J., \& Scott, W. R. (2008). Institutional exceptions on global projects: a process model. Journal of International Business Studies, 39(4), 562-588.

Pangarkar, N., \& Wu, J. (2012). Industry globalization and the performance of emerging market firms: evidence from China. International Business Review, 21(2), 196-209.

Papageorgiadis, N., Cross, A. R., \& Alexiou, C. (2014). International patent systems strength 1998 - 2011. Journal of World Business, 49(4), 586-597.

Papageorgiadis, N., Xu, Y. and Alexiou, C. (2019). The effect of European Intellectual Property institutions on Chinese outward foreign direct investment. Management and Organization Review, 15(1): 81-110.

Park, W. G. (2008). International patent protection: 1960 - 2005. Research Policy, 37(4), 761 766.

Peng, M. W., Wang, D. Y. L., \& Yi, J. (2008). An institution-based view of international business strategy: A focus on emerging economies. Journal of International Business Studies, 39(5), 920-936.

Ramasamy, B., \& Yeung, M. (2010). The determinants of foreign direct investment in services. The World Economy, 33(4), 573-596.

Rugman, A. M., \& Li, J. (2007). Will China's multinationals succeed globally or regionally? European Management Journal, 25(5), 333-343.

Rui, H., \& Yip, G. S. (2008). Foreign acquisitions by Chinese firms: a strategic intent perspective. Journal of World Business, 43(2), 213-226.

Sanfilippo, M. (2015). FDI from emerging markets and the productivity gap - an analysis on affiliates of BRICS EMNEs in Europe. International Business Review, 24(4), 665-676.

Scott, W. R. (1995). Institutions and organizations. London: Sage.

Seyoum, B. (2006). Patent protection and foreign direct investment. Thunderbird International Business Review, 48(3), 389-404. 
Shieh, B.-L., \& Wu, T.-C. (2012). Equity-based entry modes of the Greater Chinese Economic Area's foreign direct investments in Vietnam. International Business Review, 21(3), 508-517.

Smarzynska Javorcik, B. (2004). The composition of foreign direct investment and protection of intellectual property rights: evidence from transition economies. European Economic Review, 48(1), 39-62.

Sun, S. L., Peng, M. W., Ren, B., \& Yan, D. (2012). A comparative ownership advantage framework for cross-border MandAs: the rise of Chinese and Indian MNEs. Journal of World Business, 47(1), 4-16.

Taubman, A., Wager, H., \& Watal, J. (2012). A handbook on the WTO TRIPS agreement. Cambridge, UK: Cambridge University Press.

UNCTAD (1998). World investment report 1998: trends and determinants. New York and Geneva.: United Nations.

Ushijima, T. (2013). Patent rights protection and Japanese foreign direct investment. Research Policy, 42(3), 738-748.

USTR (2014). Special 301 Report by the United States Trade Representative. Available from: https://ustr.gov/sites/default/files/USTR\%202014\%20Special\%20301\%20Report $\% 20$ to\%20C ongress \%20FINAL.pdf [accessed on May 22, 2015]

Wang, C., Hong, J., Kafouros, M., \& Boateng, A. (2012). What drives outward FDI of Chinese firms?: testing the explanatory power of three theoretical frameworks. International Business Review, 21(3), 425-438.

Wei, Y. Q., Zheng, N., Liu, X. H., \& Lu, J. Y. (2014). Expanding to outward foreign direct investment or not?: a multi-dimensional analysis of entry mode transformation of Chinese private exporting firms. International Business Review, 23(2), 356-370.

Witt, M. A., \& Lewin, A. Y. (2007). Outward foreign direct investment as escape response to home country institutional constraints. Journal of International Business Studies, 38(4), 579594.

Xu, D., \& Shenkar, O. (2002). Institutional distance and the multinational enterprise. Academy of Management Review, 27(4), 608-618.

Yiu, D. W., Lau, C., \& Bruton, G. D. (2007). International venturing by emerging economy firms: the effects of firm capabilities, home country networks, and corporate entrepreneurship. Journal of International Business Studies, 38(4), 519-540.

Zhang, J., Zhou, C., \& Ebbers, H. (2011). Completion of Chinese overseas acquisitions: institutional perspectives and evidence. International Business Review, 20(2), 226-238. 
Table 1 Panel Quantile Regression Results (IPE - Papageorgiadis et al., 2014).

\begin{tabular}{lccccc}
\hline Quantile: & 0.1 & 0.25 & 0.5 & 0.75 & 0.9 \\
\hline \multirow{2}{*}{ Constant } & & & & & \\
& $-54.5185 * * *$ & $-63.2644 * * *$ & $-47.6196 * * *$ & $-35.5917 * * *$ & $-36.6997 * * *$ \\
IPE & $(10.8028)$ & $(7.9405)$ & $(5.7934)$ & $(5.2725)$ & $(7.2788)$ \\
& -2.6578 & -1.5590 & $-1.7651 *$ & $-1.6112 * *$ & $-2.3763 *$ \\
IPESQ & $(1.8629)$ & $(1.5922)$ & $(1.0247)$ & $(0.7365)$ & $(1.4056)$ \\
& 0.1963 & 0.1101 & $0.1337 *$ & $0.1163 * *$ & $0.1698 *$ \\
LGDPPC & $(0.1341)$ & $(0.1146)$ & $(0.0727)$ & $(0.0553)$ & $(0.1017)$ \\
& $1.4281 *$ & $1.3891 *$ & $0.6381 *$ & $1.0321 * *$ & $1.2567 * *$ \\
LPOP & $(0.7413)$ & $(0.7600)$ & $(0.3527)$ & $(0.4587)$ & $(0.6025)$ \\
& $2.5296 * * *$ & $2.4579 * * *$ & $2.0406 * * *$ & $1.6474 * * *$ & $1.6758 * * *$ \\
TRADE & $(0.2697)$ & $(0.2395)$ & $(0.1752)$ & $(0.1973)$ & $(0.2743)$ \\
& $0.0194 * *$ & $0.0305 * * *$ & $0.0274 * * *$ & $0.0190 * * *$ & $0.0168 * * *$ \\
ULC & $(0.0096)$ & $(0.0095)$ & $(0.0045)$ & $(0.0039)$ & $(0.0048)$ \\
& $0.0580 * *$ & $0.1365 * * *$ & $0.1425 * * *$ & $0.0633 * * *$ & $0.0851 * * *$ \\
& $(0.0366)$ & $(0.0522)$ & $(0.0424)$ & $(0.0204)$ & $(0.0296)$ \\
Pseudo R-squared & 0.3988 & 0.3839 & 0.3461 & 0.3141 & 0.3062 \\
\hline
\end{tabular}

Note: Standard errors in parentheses; $* * *, * *, *$ denote significance at $1 \%, 5 \%$ and $10 \%$ level of significance. 
Table 2 Panel Quantile Regression Results (IPRI - Property Rights Alliance)

\begin{tabular}{lccccc}
\hline Quantile: & 0.1 & 0.25 & 0.5 & 0.75 & 0.9 \\
\hline \multirow{2}{*}{ Constant } & & & & & \\
& $-41.0712 * * *$ & $-32.9453 * * *$ & $-32.1837 * * *$ & $-25.7049 * * *$ & -12.2739 \\
IPRI & $(7.5219)$ & $(6.4557)$ & $(5.6713)$ & $(6.7890)$ & $(8.3452)$ \\
& -0.5708 & -1.2474 & -0.9213 & $-1.8384 * *$ & $-1.5350 *$ \\
IPRISQ & $(0.8572)$ & $(0.9563)$ & $(1.1390)$ & $(0.7644)$ & $(0.8527)$ \\
& 0.0662 & $0.1302 *$ & 0.1039 & $0.1658 * *$ & $0.1674 * *$ \\
LGDPPC & $(0.0737)$ & $(0.0733)$ & $(0.0872)$ & $(0.0742)$ & $(0.0682)$ \\
& -0.2729 & -0.2112 & 0.1025 & 0.4993 & -0.0448 \\
LPOP & $(0.3825)$ & $(0.3827)$ & $(0.4143)$ & $(0.5213)$ & $(0.6123)$ \\
& $2.4600 * * *$ & $2.0159 * * *$ & $1.7889 * * *$ & $1.5077 * * *$ & $1.0189 * * *$ \\
TRADE & $(0.2434)$ & $(0.2395)$ & $(0.1996)$ & $(0.2110)$ & $(0.2881)$ \\
& $0.0352 * * *$ & $0.0291 * * *$ & $0.0238 * * *$ & $0.0167 * * *$ & 0.0043 \\
ULC & $(0.0054)$ & $(0.0041)$ & $(0.0039)$ & $(0.0040)$ & $(0.0056)$ \\
& $0.0376 * * *$ & $0.0509 * * *$ & $0.0514 * * *$ & $0.0412 * * *$ & $0.0463 *$ \\
& $(0.0094)$ & $(0.0107)$ & $(0.0149)$ & $(0.0106)$ & $(0.0270)$ \\
Pseudo R-squared & 0.3988 & 0.4446 & 0.3816 & 0.3535 & 0.3173 \\
\hline
\end{tabular}

Note: Standard errors in parentheses; $* * * * *, *$ denote significance at $1 \%, 5 \%$ and $10 \%$ level of significance. 


\section{Appendix}

Table 1. List of Countries

\begin{tabular}{clll}
\hline a/a & Country & OECD member & EU member \\
\hline 1 & Austria & OECD & EU \\
2 & Belgium & OECD & EU \\
3 & Czech Republic & OECD & EU \\
4 & Denmark & OECD & EU \\
5 & Finland & OECD & EU \\
6 & France & OECD & EU \\
7 & Germany & OECD & EU \\
8 & Greece & OECD & EU \\
9 & Hungary & OECD & EU \\
10 & Ireland & OECD & EU \\
11 & Italy & OECD & EU \\
12 & Netherlands & OECD & EU \\
13 & Norway & OECD & Non-EU \\
14 & Poland & OECD & EU \\
15 & Portugal & OECD & EU \\
16 & Romania & Non-OECD & EU \\
17 & Russia & Non-OECD & Non-EU \\
18 & Slovakia & OECD & EU \\
19 & Spain & OECD & EU \\
20 & Sweden & OECD & EU \\
21 & Switzerland & OECD & Non-EU \\
\hline & & &
\end{tabular}




\section{Appendix}

Table 3. Descriptive statistics

\begin{tabular}{lccccccccc}
\hline & LOFDI & IPE & IPRI & LGDPPC & LPOP & TRADE & LBPROD & LBPROD & ULC \\
\hline Mean & 4.0787 & 7.0306 & 6.9293 & 10.3393 & 16.5397 & 96.4472 & 1.4667 & 1.4667 & 97.1744 \\
Median & 4.5362 & 7.3703 & 7.2090 & 10.5996 & 16.1682 & 83.1433 & 1.1821 & 1.1821 & 98.1215 \\
Maximum & 9.9068 & 9.7000 & 8.7850 & 11.4251 & 18.7898 & 216.2428 & 22.4948 & 22.4948 & 162.3868 \\
Minimum & -3.2189 & 3.2469 & 3.2000 & 8.6953 & 15.2009 & 45.6091 & -4.6557 & -4.6557 & 43.5686 \\
Std. Dev. & 2.7074 & 1.8238 & 1.3177 & 0.6659 & 1.01853 & 40.1956 & 2.6096 & 2.6096 & 11.4373 \\
Skewness & -0.4981 & -0.3051 & -0.6427 & -0.5426 & 0.72156 & 0.8014 & 2.3981 & 2.3981 & 0.56306 \\
Kurtosis & 2.9779 & 1.8345 & 2.6979 & 2.2613 & 2.27747 & 2.5976 & 19.2406 & 19.2406 & 12.4552 \\
Jarque-Bera & 11.0459 & 19.6853 & 13.5846 & 19.6012 & 29.6277 & 31.0645 & 3106.561 & 3106.561 & 974.6894 \\
Probability & 0.0039 & 0.0001 & 0.0011 & 0.0001 & 0.0000 & 0.0000 & 0.0000 & 0.0000 & 0.0000 \\
Observations & 267 & 273 & 187 & 273 & 273 & 273 & 260 & 260 & 258 \\
\hline
\end{tabular}

Note: The letter L before a variable's name denotes a logarithmic transformation. 
Table 4. Cross-correlations table

\begin{tabular}{lrrrrrrrr}
\hline & FDIS & \multicolumn{1}{c}{ IPE } & \multicolumn{1}{c}{ IPRI } & GDPPC & \multicolumn{1}{c}{ POP } & TRADE & LBPROD & \multicolumn{1}{c}{ ULC } \\
\hline OFDI & 1.0000 & -0.0422 & -0.0114 & 0.0362 & 0.4090 & -0.1318 & 0.0212 & 0.4474 \\
IPE & -0.0422 & 1.0000 & 0.9292 & 0.8067 & -0.4633 & 0.1222 & -0.1032 & -0.1483 \\
IPRI & -0.0114 & 0.9292 & 1.0000 & 0.8081 & -0.5010 & 0.1809 & -0.1205 & -0.0388 \\
GDPPC & 0.0362 & 0.8067 & 0.8081 & 1.0000 & -0.3561 & 0.0100 & -0.1094 & -0.0450 \\
POP & 0.4090 & -0.4633 & -0.5010 & -0.3561 & 1.0000 & -0.5054 & 0.0408 & 0.3265 \\
TRADE & -0.1318 & 0.1222 & 0.1809 & 0.0100 & -0.5054 & 1.0000 & 0.2679 & -0.0341 \\
LBPROD & 0.0212 & -0.1032 & -0.1205 & -0.1094 & 0.0408 & 0.2679 & 1.0000 & -0.0936 \\
ULC & 0.4474 & -0.1483 & -0.0388 & -0.0450 & 0.3265 & -0.0341 & -0.0936 & 1.0000 \\
\hline
\end{tabular}


Table 5. Quantile tests

\begin{tabular}{llcc}
\hline & Test & IPE model & IPRI model \\
\hline a. & Quantile Slope Equality Test (Wald test) & $57.56(0.000)$ & $43.12(0.009)$ \\
b. & Symmetric Quantiles Test (Wald test) & $19.50(0.147)$ & $1.34(0.987)$ \\
\hline
\end{tabular}

The p-values of the Wald test-statistics in parentheses. 
Figure 1. IPE and IPESQ Plots
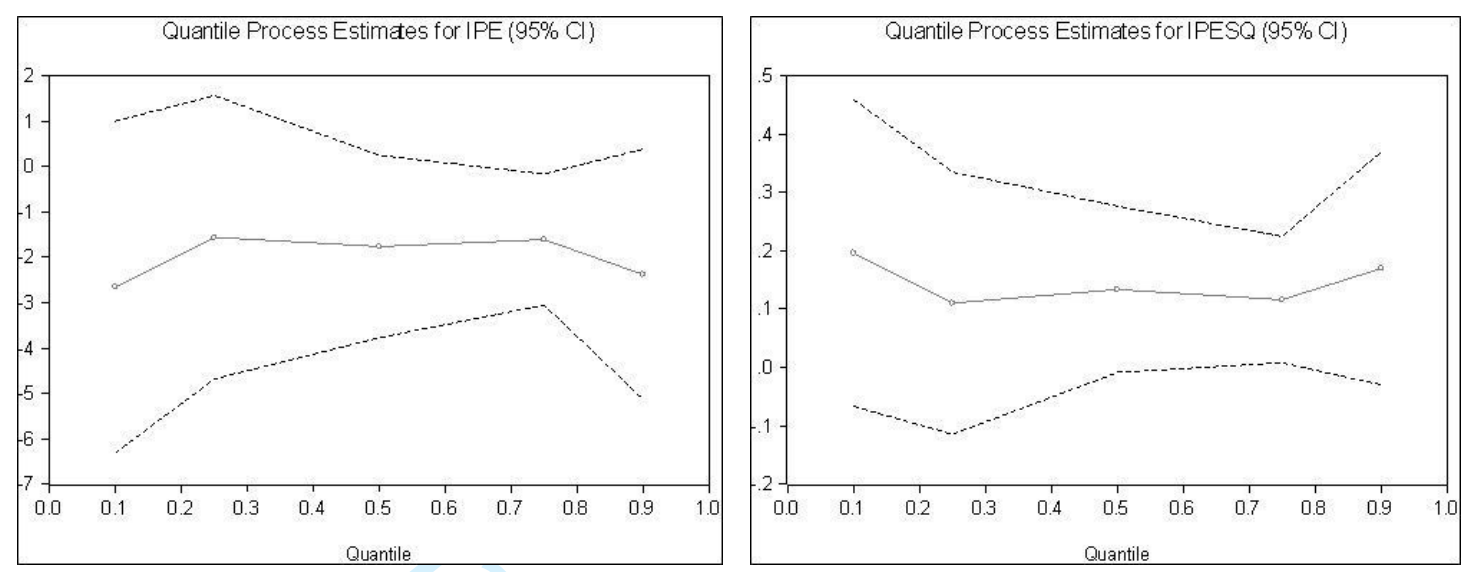
Figure 2. IPRI and IPRISQ Plots
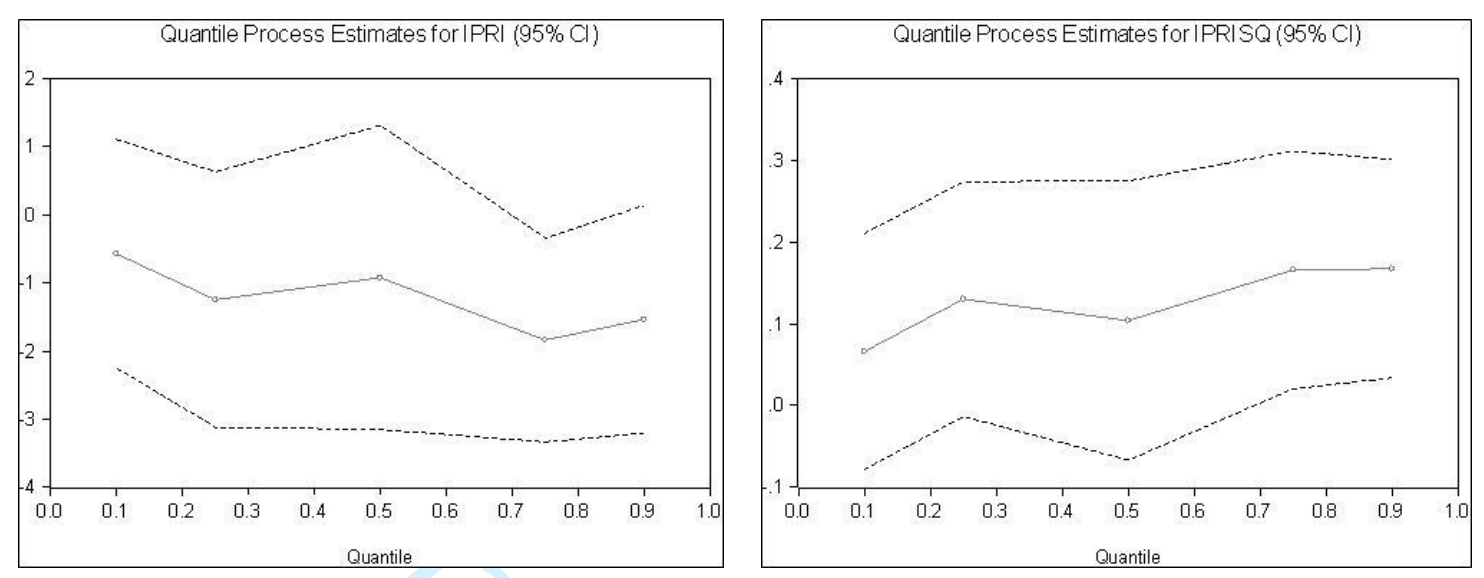


\section{Appendix}

Table 2. List of Variables.

\begin{tabular}{|c|c|c|}
\hline Variable & Definition & Source \\
\hline OFDI & $\begin{array}{l}\text { Outward Foreign Direct Investment, stock } \\
\text { (constant US\$) }\end{array}$ & $\begin{array}{l}\text { Ministry of Commerce, People's } \\
\text { Republic of China. }\end{array}$ \\
\hline IPE & Index for Patent Enforcement & $\begin{array}{l}\text { Papageorgiadis et al. (2014) } \\
\text { ttps://www.cranfield.ac.uk/som/research- } \\
\text { projects/index-of-patent-systems- } \\
\text { strength-1998-2015 }\end{array}$ \\
\hline IPRI & International Property Rights Index & $\begin{array}{l}\text { Property Rights Alliance. } \\
\text { http://internationalpropertyrightsindex.org }\end{array}$ \\
\hline POP & Population, total & United Nations, World Indicators \\
\hline GDPPC & $\begin{array}{l}\text { Gross Domestic Product per capita (constant } \\
\text { US\$) }\end{array}$ & OECD \\
\hline TRADE & Trade in goods and services ( $\%$ of GDP) & OECD \\
\hline ULC & $\begin{array}{l}\text { Unit Labour Costs, Cost of labour per unit } \\
\text { of output produced }(\%)\end{array}$ & OECD \\
\hline LBPROD & $\begin{array}{l}\text { Labour Productivity, Labour } \\
\text { productivity/Labour utilization, annual } \\
\text { growth rate }(\%)\end{array}$ & OECD \\
\hline
\end{tabular}

